\title{
PEMBERDAYAAN PEMUDA DESA MELALUI BUDI DAYA JAMUR TIRAM DI DESA LEMBAH SEMPAGE NARMADA LOMBOK BARAT
}

\author{
Fathurrahman Muhtar, Siti Hajaroh \\ Institut Agama Islam Negeri Mataram \\ E-mail: fathurrahman.muhtar@yahoo.com, hajaroh.saif@gmail.com
}

\begin{abstract}
Abstrak. Pemberdayaan masyarakat, secara lugas dapat diartikan sebagai suatu proses yang membangun manusia atau masyarakat melalui pengembangan kemampuan masyarakat, perubahan perilaku masyarakat, dan pengorganisasian masyarakat. Salah satu pemberdayaan masyarakat adalah pemberdayaan pemuda desa melalui budi daya jamur Tiram di desa Lembah Sempage Narmada Lombok Barat. Adapun alasan memilih subyek dampingan adalah: 1) dengan pertimbangan kondisi Narmada yang jenderung dingin sangat tepat untuk budi daya jamur, 2) Biaya budi daya tidak begitu mahal, 3). Bahan-bahan untuk budidaya jamur mudah didapatkan, dengan memanfaatkan lingkungan sekitar seperti Serbuk gergaji kayu, Bekatul sebanyak, Kapur $\mathrm{CaCO}_{3}$ sebanyak, dan Air. Dari observasi awal kondisi dampingan saat ini adalah: pertama: pemuda di desa lembah sempage tidak memiliki kemampuan pemberdayaan lingkungan. Kedua, Pemuda desa lembah sempage hanya mengandalkan hasil pertanian dan perkebunan yang bersifat musiman. Adapun hasil pengabdian para pemuda desa mampu membuat bagblok jamur dan menyemai bibit jamur ke dalam bagblok (media tanam jamur)
\end{abstract}

Kata Kunci: Pemberdayaan, Budi daya Jamur, Bagblok, masyarakat.

\section{PENDAHULUAN}

Pemberdayaan masyarakat muncul karena adanya suatu kondisi sosial ekonomi masyarakat yang rendah mengakibatkan mereka tidak mampu dan tidak tahu. Ketidakmampuan dan ketidaktahuan masyarakat mengakibatkan produktivitas mereka rendah. Pemberdayaan masyarakat dila ksanakan melalui: (1) Pengembangan masyarakat, (2) Pengorganisasian masyarakat.

Apa yang dikembangkan dari masyarakat, yaitu potensi atau kemampuannya, dan sikap hidupnya. Kemampuan masyarakat meliputi antara lain kemampuan untuk bertani, berternak, melakukan wirausaha, atau keterampilan membuat home industri; dan masih banyak lagi kemampuan dan keterampilan masyarakat yang dapat dikembangkan.

Dalam rangka mengembangkan kemampuan dan keterampilan masyarakat, dapat dilakukan dengan berbagai cara. Contoh dengan mengadakan pelatihan atau mengikutkan masyarakat pada pelatihan-pelatihan pengembangan kemampuan dan keterampilan yang dibutuhkan. Dapat juga dengan mengajak masyarakat 
mengunjungi kegiatan di tempat lain dengan maksud supaya masyarakat dapat melihat sekaligus belajar, kegiatan ini sering disebut dengan istilah studi banding. Sikap hidup yang perlu diubah tentunya sikap hidup yang merugikan atau menghambat peningkatan kesejahteraan hidup. Mengubah sikap bukan pekerjaan mudah. Mengapa? Karena masyarakat sudah bertahun-tahun bahkan puluhan tahun sudah melakukan hal itu. Untuk itu memerlukan waktu yang cukup lama untuk melakukan perubahan sikap.

Caranya adalah dengan memberikan penyadaran bahwa apa yang mereka lakukan selama ini merugikan mereka. Hal ini dapat dilakukan dengan memberikan banyak informasi dengan menggunakan berbagai media, seperti buku-buku bacaan, mengajak untuk melihat tempat lain, menyetel film penerangan, dan masih banya cara lain.

Pada pengorganisasian masyarakat, kuncinya adalah menempatkan masyarakat sebagai pelakunya. Untuk itu masyarakat perlu diajak mulai dari perencanaan kegiatan, pelaksanaan, sampai pemeliharaan dan pelestarian. Pelibatan masyarakat sejak awal kegiatan memungkinkan masyarakat memiliki kesempatan belajar lebih banyak. Pada awal-awal kegiatan mungkin "pendamping" sebagai pendamping akan lebih banyak memberikan informasi atau penjelasan bahkan memberikan contoh langsung. Pada tahap ini masyarakat lebih banyak belajar namun pada tahap-tahap berikutnya "pendamping" harus mulai memberikan kesempatan kepada masyarakat untuk mencoba melakukan sendiri hingga mampu atau bisa. Jika hal ini terjadi maka di kemudian hari pada saat "pendamping" meninggalkan masyarakat tersebut, masyarakat sudah mampu untuk melakukannya sendiri atau mandiri.

Salah satu program dampingan yang ingin dikembangkan adalah budi daya Jamur tiram. Budi daya jamur perlu dikembangkan mengingat tingginya minat masyarakat Indonesia mengkonsumsi jamur tiram ini menyebabkan kebutuhan akan jamur tiram menjadi meningkat, terutama bagi para penyaji kuliner yang di mana daftar menunya selalu menghadirkan olahan jamur tiram. Dengan keadaan seperti itu maka tidak heran banyak orang yang melirik cara budidaya jamur tiram ini, dengan tujuan untuk membudidayakannya (home industry). Hal ini bisa menjadi ladang usaha baru bagi siapapun yang ingin menekuni budidaya jamur tiram ini. Dengan tingginya minat masyarakat Indonesia mengkonsumsi jamur tiram ini 
Fathurrahman Muhtar, Siti Hajaroh, Pemberdayaan Pemuda Desa...

menyebabkan kebutuhan akan jamur tiram menjadi meningkat, terutama bagi para penyaji kuliner yang dimana daftar menunya selalu menghadirkan olahan jamur tiram. Dengan keadaan seperti itu maka tidak heran banyak orang yang melirik cara budidaya jamur tiram ini, dengan tujuan untuk membudidayakannya (home industry). Hal ini bisa menjadi ladang usaha baru bagi siapapun yang ingin menekuni budidaya jamur tiram ini. Atas dasar itulah maka kegiatan pemberdayaan budi daya jamur tiram merupakan solusi yang ingin diterapkan dalam kegiatan pengabdian ini.

\section{PEMBAHASAN}

\section{Pemberdayaan Masyarakat}

Pemberdayaan menurut arti secara bahasa adalah proses, cara, perbuatan membuat berdaya, yaitu kemampuan untuk melakukan sesuatu atau kemampuan bertindak yang berupa akal, ikhtiar atau upaya (Depdiknas, 2003). Masyarakat adalah kesatuan hidup manusia yang berinteraksi menurut suatu sistem adat istiadat tertentu yang bersifat kontinyu, dan yang terikat oleh suatu rasa identitas bersama (Koentjaraningrat, 2009). Dalam beberapa kajian mengenai pembangunan komunitas, pemberdayaan masyarakat sering dimaknai sebagai upaya untuk memberikan kekuasaan agar suara mereka didengar guna memberikan kontribusi kepada perencanaan dan keputusan yang mempengaruhi komunitasnya (Foy, 1994). Pemberdayaan adalah proses transisi dari keadaan ketidakberdayaan ke keadaan kontrol relatif atas kehidupan seseorang, takdir, dan lingkungan (sadan,1997).

Menurut Mubarak (2010) pemberdayaan masyarakat dapat diartikan sebagai upaya untuk memulihkan atau meningkatkan kemampuan suatu komunitas untuk mampu berbuat sesuai dengan harkat dan martabat mereka dalam melaksanakan hak-hak dan tanggung jawabnya selaku anggota masyarakat.

Pada Pemberdayaan pendekatan proses lebih memungkinkan pelaksanaan pembangunan yang memanusiakan manusia. Dalam pandangan ini pelibatan masyarakat dalam pembangunan lebih mengarah kepada bentuk partisipasi, bukan dalam bentuk mobilisasi. Partisipasi masyarakat dalam perumusan program membuat masyarakat tidak semata-mata berkedudukan sebagai konsumen program, tetapi juga sebagai produsen karena telah ikut serta terlibat dalam proses 
pembuatan dan perumusannya, sehingga masyarakat merasa ikut memiliki program tersebut dan mempunyai tanggung jawab bagi keberhasilannya serta memiliki motivasi yang lebih bagi partisipasi pada tahaptahap berikutnya (Soetomo, 2006).

\section{Sekilas Tentang Jamur}

Jamur adalah spesies yang secara tampilan makrokoskopis mirip seperti tumbuhan, namun tidak dimasukkan kedalam kingdom (kerajaa) tumbuhan. Jamur terpisah kedalam kingdom tersendiri yaitu kongdom fungi (jamur). Hal ini dikarenakan ada ciri-ciri khusus jamur yang tidak dimiliki oleh tumbuhan atau ada ciri-ciri tumbuhan yang tidak dimiliki oleh jamur. Struktur didinding sel jamur sebagian besar tersusun oleh zat katin sedangkan pada tumbuhan sebagian besar oleh selulosa, hemiselulosa dan lignin. Jamur tidak memiliki akar, batang, daun dan bunga sejati. Strukturnya lebih sederhana daripada tumbuhan. Jamur tidak memiliki klorofil sehingga tidak mampu berfotosintesis (memproduksi makanannya sendiri). Hidupnya bergantung pada sisa-sisa bahan organik yang telah mati.

Jamur adalah organisme yang terdapat dimana-mana di bumi, baik di daerah tropik, subtropik, di kutub utara, maupun antarika. Fungi juga ditemukan di darat, di perairaian tawar, di laut, di mangrove, di bawah permukaan tanah, di kedalaman laut, dipengunungan, maupun di udara. Banyak faktor lingkungan yang mempengaruhi kehidupan fungi, antara lain kelembapan, suhu, keasaman substrat, pengudaraan, dan kehadiran nutrien-nutrien yang diperlukan.

Sedangkan pendapat lain mengatakan bahwa Fungi adalah nama regnum dari sekelompok besar makhluk hidup eukariotik heterotrof yang mencerna makanannya di luar tubuh lalu menyerap molekul nutrisi ke dalam sel-selnya. Fungi memiliki bermacam-macam bentuk. Awam mengenal sebagian besar anggota Fungi sebagai jamur, kapang, khamir, atau ragi, meskipun seringkali yang dimaksud adalah penampilan luar yang tampak, bukan spesiesnya sendiri. Kesulitan dalam mengenal fungi sedikit banyak disebabkan adanya pergiliran keturunan yang memiliki penampilan yang sama sekali berbeda (ingat metamorfosis pada serangga atau katak). Fungi memperbanyak diri secara seksual dan aseksual. 
Sedangkan dari sudut lain mengatakan bahwa fungi adalah mikroorganisme eukaryotik yang hidup secara saprofit karena tidak dapat berfotosintesa. Pada dasarnya sel -sel fungi hampir sama dengan sel - sel hewan. Bahkan hal ini juga yang menjadi salah satu alasan mengapa sulit ditemukan strategi yang tepat dalam mengobati infeksi oleh jamur tanpa berefek toksik bagi inang / host nya. Di alam ini fungi dapat bersifat sangat merugikan manusia dengan menimbulkan infeksi (penyakit) dan toksin yang dihasilkan ataupun bersifat menguntungkan dengan menghasilkan produk - produk yang dapat digunakan oleh manusia sebagai contoh antibiotika, vitamin, asam organik dan enzim.

Jamur merupakan organisme eukariotik yang bersel satu dan tidak memiliki klorofil. Jamur atau fungi masuk ke dalam organisme yang memperoleh makanan dari organisme lainnya atau biasa disebut heterotrof. Sehingga ia hidup dengan menguraikan makanan dari bahan organik di sekitar lingkungannya.

Secara umum jamur hidup melalui tiga cara yaitu saprofit, parasit dan mutualisme. Saprofit yaitu cara hidup dengan mengurai sampah organik menjadi anorganik. Sedangkan parasit yaitu cara hidup dengan memperoleh bahan organik dari inangnya (tumpangan), Dan mutualisme yaitu hidup dengan organisme lain agar sama-sama untung. Jamur hanya bisa tumbuh di lingkungan dengan suhu, kelembaban yang sesuai, kemudian pH kurang dari 7 dan lingkungan yang beroksigen meskipun oksigennya rendah.

\section{Teknik Budi Daya Jamur Tiram}

Secara tradisional, di Jepang, bibit ditanam di dalam lubang atau garisan di kayu kering. Pengeringan dilakukan dengan tenaga sinar matahari atau listrik. Dalam budidaya modrn, media tumbuh yang digunakan berupa kayu tiruan (log) yang dibuat dalam bentuk silinder. Komposisi media ini berupa sumber kayu (gergaji kayu, ampas tebu), sumber gula (tepung-tepungan), kapur, pupuk $P$, dan air.

Pertumbuhan yang optimal dapat dicapai bila lingkungannya sesuai serta tersedia nutrisiyang cukup. Protoplas sel memerlukan nitrogen, fosfor, dan nutrisi lai. Karbon selain diperlukan untuk pembentukan protoplasma, juga diperlukan sebagai sumber energy. Sehingga karbon lebih banyak dibutuhkan disbanding 
dengan nitrogen. Nitrogen dibutuhkan untuk pembentukan asam nukleat. Sedangkan protein dan kitin diperlukan untuk pembentukan dinding sel jamur.

Media tempat tumbuh merupakan sumber energy utama bagi jamur tiram. Kehadiran mikroorganisme lain dapat menyebabkan persaingan dalam mendapatkan nutrisi, sehingga jamur yang diharapkan tidak dapat tumbuh dengan optimal. Bahkan, sebagian dari competitor tersebut dapat mengeluarkan senyawa yang bersifat toksin terhadap organism disekitarnya. Sterilisasi media merupakan cara yang efektif untuk membebaskan media tanam dari kehadiran jasad asing di dalam media tanam yang tidak diharapkan. Kondisi di atas lebih mudah dicapai didaerah dataran tinggi sekitar 700-800 m dpl. Kemungkinan budidaya jamur di dataran rendah tidak mustahil, asalkan iklim ruang penyimpanan dapat diatur dan disesuaikan dengan kebutuhan jamur.

1. Pembibitan

Bibit yang dapat digunakan adalah F3. Bibit ini dapat dibuat atau diperoleh dari petani jamur yang sudah bisa membuat bibit bibit jamur. Untuk membuat bibit sendiri, diperlukan alat dan bahan yang steril karena proses ini sangat rentan terhadap kontaminasi. Sterilisasi pembuatan bibit biasa menggunakan laminar flow atau transfer box.

2. Alat dan bahan

Untuk membudidayakan jamur tiram, diperlukan alat dan bahan sebagai berikut; Kompor minyak tanah, Drum berdiameter $80 \mathrm{~cm}$, tinggi $96 \mathrm{~cm}$, Rak, dengan luas $3 \mathrm{~m}^{2}$, pH meter, Thermometer, Sprayer / penyemprot, dengan pipa paralon 2 inci sebanyak 300 buah, Cincin, Lampu spirtus, dengan volume 30 liter, Baskom plastic, Sekpo, Serbuk kayu albasia sebanyak 10,5 kg, Dedak halus sebanyak $21 \mathrm{~kg}$, Tepung jagung sebanyak 0,6 kg, TSP murni 1 kg, Kapur 3 buah, Bibit jamur F3 sebanyak 3 buah, Alcohol 95\% sebanyak 1 liter, Kantung plastic transparan $(20 \times 35 \times 0,5) \mathrm{cm}$ sebanyak 300 buah, Kertas roti $10 \times 10$ sebanyak 300 buah, Karet gelang tahan panas 600 buah, Air sumur 30 liter.

Adapun proses pembuatan jamur tiram adalah sebagai berikut; Serbuk gergaji dipilih dan dibersihkan. Bagian yang besar dan tajam dibuang karena dapat merusak plastic substrat, Bahan yang sudah ada dicampur sesuai komposisi takaran 
dalam jolang/baskom plastic. Aduk sampai merata, jangan sampai ada gumpalangumpalan. Bahan yang dicampurkan untuk menghasilkan 100 log adalah sebagai berikut : Serbuk gergaji atau ampas tebu halus $10,5 \mathrm{~kg}$, Tepung jagung $0,6 \mathrm{~kg}$, Dedak halus $21 \mathrm{~kg}$, TSP $1 \mathrm{~kg}$, Kapur 3 buah

Beri air secukupnya, dengan kandungan air $60 \%$ dan $\mathrm{pH}$ media diukur.

1. Campuran bahan dimasukan ke dalam plastic transparan dengan ukuran $20 \mathrm{x}$ $35 \mathrm{~cm}$ dan tebal 0,5. Media harus dipadatkan agar terbentuk log yang baik. Media yang bagus adalah kepadatannya merata. Jangan lupa, ujung plastic bagian bawah ditusuk jari telunjuk supaya masak. Hal ini dilakukan agar bahan yang dimasukkan dan dipadatkan bisa duduk posisinya (tidak miring). Pengisian dilakukan tidak terlalu penuh, tapi disisakan $15 \mathrm{~cm}$ untuk memudahkan dalam mengikat.

2. Tiap log ditimbang beratnya, yaitu sebanyak $1,2 \mathrm{~kg}$.

3. Sisa ujung plastic ke dalam cincin dilipat keluar, lalu diikat mulut plastic tersebut dengan karet tahan panas.

4. Tutup mulut log tersebut dengan kapaskemudian tutup lagi dengan kertas, lalu diikat lagi dengan karet.

5. Dilakukan pengukusan terhadap log media selama 12 jam.

6. Lamanya pengukusan dihitung setelah air di dalam drum mendidih.

7. Setelah selesai pengukusan, media di angkat dari drum. Lalu, biarkan selama 8 jam atau sampai dingin pada ruangan yang tertutup. Untuk selanjutnya, dilakukan penanaman bibit.

8. Setelah media dingin, baru dilakukan penanaman bibit, caranya:

a. Penanaman bibit dilakuan di ruangan tertutup.

b. Semprot isi ruangan dengan alcohol $95 \%$.

c. Gunakan sarung sarung tangan dan semprot dengan alcohol $95 \%$

d. Untuk memudahkan penanaman bibit, media yang akan diinokulasi disimpan di depan dekat tangan kiri. Bibit yang akan ditanamkan disimpan di depan dekat tangan kanan. Antara media yang akan ditanami dan bibit, disimpan lampu spirtus.

e. Buka karet, kertas penutup, serta kapas penutup media. 
f. Masukkan 3 sendok makan bibit untuk satu log media.

g. Setiap gerakan sendok yang dipakai, dipanaskan dengan api dari lampu spirtus.

h. Media yang sudah ditanami bibit tersebut ditutup kembali dengan kapas.

i. Penanaman bibit dikerjakan dengan cepat, tetapi harus teliti.

9. Media yang sudah ditanami bibit disimpan di atas rak.

10. Biarkan sampai seluruh media diisi miselium jamur.

11. Miselium tumbuh memenuhi log media. Setelah seluruh log media ditumbuhi miselium, tutup kapas dan cincin pada bagian atas log tersebut dibuka.

12. Kelembapan lingkungan dipertahankan dengan menyemprot menggunakan sprayer.

13. Tubuh buah yang sudah cukup mekar dapat dipanen.

\section{Proses Pelaksanaan Kegiatan}

Kegiatan ini berawal dari permasalahan yang dihadapi oleh sebagian masyarakat di desa Lebah Sempage yaitu kurang kemampuan memanfaatkan potensi lingkungan desa, diantaranya terbuangnya serbuk hasil gergajian masyarakat yang tidak dapat dimanfaatkan oleh masyarakat. Tingkat pengangguran masyarakat masih tinggi, sebagian masyarakat adalah petani dan mengelola perkebunan. Oleh sebab itu, untuk mengatasi persoalan tersebut diadakan pelatihan budi daya jamur, dengan memanfaatkan limbah serbuk gergaji, oleh sebab itu, dalam pelatihan ini diberikan pemahaman tentang: 1) memahami pentingnya pengembangan jamur bagi peningkatan ekonomi keluarga dan masyarakat. 2) memahami cara membuat baglog dengan memanfaatkan limbah serbuk gergaji. 3) memahami cara mengukus media jamur (baglog). 3) memberikan pemahaman dalam membudidayakan jamur.

\section{Metode Kegiatan}

Mendatangkan seorang ahli dalam pembudidayaan jamur. Kerangka pemecahan masalah yang digunakan adalah memberikan pelatihan dengan materi yang sangat sederhana dan mudah dimengerti serta dengan bahasa yang mudah difahami. Setelah materi dipahami langkah selanjutnya praktek pembuatan media 
tanam jamur. Kemudian membuat sentra budidaya jamur pada satu tempat, sebagai percontohan.

Metode kegiatan pelatihan ini dilakukan berdasarkan pendekatan proses pembelajaran teori dan pembelajaran praktek. Perbandingan antara pembelajaran teori dengan pembelajaran praktek berkisar dengan perbandingan sekitar $1: 1,5$. Dalam kegiatan penyuluhan dan pelatihan ini pendekatan yang digunakan bersifat 'persuasif-edukatif, dengan ini dimaksudkan untuk memberikan pengetahuan, pemahaman, dan keterampilan budi daya jamur.

Adapun metodenya: ceramah, diskusi, demonstrasi, dan praktek/latihan, melalui tahapan sebagai berikut: - metode ceramah dan diskusi disampaikan pada waktu menjelaskan konsep budi daya jamur secara teoritis - metode demonstrasi dan praktek digunakan pada waktu latihan memahami tehnik budi daya jamur.

1. Rancangan Evaluasi.

Untuk mengetahui tingkat keberhasilan program bagi peserta, maka dilakukan evaluasi dengan instrumen-instrumen evaluasi yang telah dipersiapkan sebelumnya menyangkut pengetahuan dan keterampilan peserta. Evaluasi dilakukan secara lisan dan spontan berupa tanya jawab sebelum dan setelah pelatihan. Materi yang belum jelas diterangkan kembali serta kesalahan dalam praktikum langsung dijelaskan kembali.

2. Pembekalan Kepada Masyarakat

Pembekalan memberikan pemahaman tentang peluang pengembangan usaha budidaya jamur, untuk memotivasi masyarakat membudidayakan jamur, dan tekhnik pembuatan baglog (media tanam jamur) pengukusan Bagloq, serta penanaman bibit jamur. Pembekalan ini dihadiri oleh 24 orang masyarakat dilingkungan lebah sempage kecamatan Narmada Kabupaten Lombok Barat.

3. Praktek Pembuatan Bagblog (Media Tanam Jamur)

Setelah masyarakat memahami tekhnik budi daya jamur, masyarakat langsung mempraktekkan pemahaman mereka tentang teknik pembuatan Bagloq dan pengukusan Baglog yang di pandu oleh Instruktur Muhammad Hadi Pratama S.P dari dinas pertanian Propinsi NTB.

4. Memberikan Bantuan 1000 baglog kepada masyarakat lebah sempage. 
Sebagai modal awal pengembangan budi daya jamur Dosen pengabdian madrasah binaan memberikan bantuan 1000 baglok jamur dan tungku pengukusan baglog jamur sebagai modal awal untuk usaha pengembangan jamur, kepada kelompok usaha tani pengembangan jamur yang baru dibentuk oleh kepala desa lebah sempage.

\section{KESIMPULAN}

Bertitik tolak dari proses pelaksanaan pengabdian, maka dapat diambil kesimpulan sebagai berikut; Budi daya jamur merupakan sesuatu hal yang sangat baru dan menarik untuk dikembangkan di masyarakat desa Lebah Sempage. Dengan iklim yang baik serta melimpahnya material dalam membuat media budi daya jamur merupakan keutungan yang dapat mendukung tercapainya hasil yang baik dari pelatihan ini. Kegiatan pelatihan bagi masyarakat lebah sempage meliputi: pemahaman dasar tentang penting budidaya jamur, tehnik pembuatan media jamur dan pemeliharaan jamur yang baik.

Pelaksanaan pengabdian pada masyarakat yang dilakukan oleh para dosen yang dibiayai oleh dana rutin IAIN Mataram, sudah saatnya dikembangkan melalui kerjasama dengan pihak-pihak terkait dan berkepentingan, misalnya dengan Pemerintah Daerah. Juga sebaiknya dilakukan secara terpadu dan berkelanjutan, tentunya dengan anggaran yang memadai, sehingga dapat lebih meningkatkan bobot dan kualitas 'isi' pengabdian pada masyarakat yang secara periodik dilaksanakan oleh para Dosen IAIN Mataram.

\section{DAFTAR PUSTAKA}

Chambers, R. Rural Development : Putting The Last First, London: New York, 1985.

Foy, Nancy, Empowering People at Work, London: Grower Publishing Company, 1994.

Friedman, John, Empowerment The Politics of Alternative Development, Blackwell Publishers, Cambridge, USA, 1992.

Glasserfield, E, A Constructivist Approach to Teaching. In L. Steffe \& J. Gale (Eds.), Constructivism In Education. Hillsdale NJ, Lawrence Erlbaum, 1987. 
Fathurrahman Muhtar, Siti Hajaroh, Pemberdayaan Pemuda Desa...

Nugraha, Tatang, Kiat Sukses Budi Daya Jamur Tiram, Bandung: Yrama Widya, 2013.

Pearsons, Talcot, The Social System. Routledge is an imprint of Taylor \& Francis, an informa company, 1991.

Prijono, Onny S. dan Pranarka A.M.W. (ed.), Pemberdayaan: Konsep, Kebijakan dan Implementasi, Jakarta: Centre for Strategic and International Studies (CSIS), 1996.

Rusmanto, Joni, Gerakan Sosial Sejarah Perkembangan Teori Kekuatan dan Kelemahannya, Sidoarjo: Zifatama Publishing, 2013.

Shucksmith, Mark, Future Direction in Rural Development. Carnegie UK Trust, England. 2013.

Soetomo, Strategi-strategi Pembangunan Masyarakat, Yogyakarta: Penerbit Pustaka Pelajar, 2006. 